\section{Hepatitis Awareness Month and Testing Day, May 2018}

The United States commemorates National Hepatitis Awareness Month each May, and May 19 is designated as Hepatitis Testing Day. Viral hepatitis still persists as a major public health threat despite availability of preventive measures such as vaccines and therapies, including a curative treatment for hepatitis $\mathrm{C}$ virus (HCV) infection.

New cases of hepatitis B virus (HBV) and HCV infections are on the rise, largely among persons who inject drugs, with some attributed to the current U.S. opioid epidemic (1). Recent hepatitis A outbreaks have also occurred among unvaccinated injection drug users and homeless persons (2). Since August 2016, CDC has responded to hepatitis A outbreaks with high HBV/HCV co-infection, hospitalization, and mortality rates in multiple states (https://www.cdc. gov/hepatitis/outbreaks/2017March-HepatitisA.htm). New cases of perinatal HBV infection also continue (1); recently, CDC updated recommendations to strengthen vaccination among newborns and manage pregnant women (3).

This issue of $M M W R$ includes an article about the promising outcomes of three HBV programs that implemented community-based services to improve HBV testing, linkage to care, and treatment among persons born in intermediate-high prevalence countries (4).

\section{References}

1. CDC. Viral hepatitis surveillance-United States, 2016. Atlanta, GA: US Department of Health and Human Services; 2016. https://www.cdc.gov/ hepatitis/statistics/2016surveillance/pdfs/2016HepSurveillanceRpt.pdf

2. Williams WW, Lu PJ, O'Halloran A, et al. Surveillance of vaccination coverage among adult populations - United States, 2015. MMWR Surveill Summ 2017;66(No. SS-11). https://doi.org/10.15585/mmwr.ss661 la1

3. Schillie S, Vellozzi C, Reingold A, et al. Prevention of hepatitis B virus infection in the United States: recommendations of the Advisory Committee on Immunization Practices. MMWR Recomm Rep 2018;67(No. RR-1). https://doi.org/10.15585/mmwr.rr6701al

4. Harris AM, Link-Gelles R, Kim K, et al. Community-based services to improve testing and linkage to care among non-U.S.-born persons with chronic hepatitis B virus infection - three U.S. programs, October 2014 September 2017. MMWR Morb Mortal Wkly Rep 2018;67:541-6.

\section{Community-Based Services to Improve Testing and Linkage to Care Among Non-U.S.-Born Persons with Chronic Hepatitis B Virus Infection - Three U.S. Programs, October 2014- September 2017}

Aaron M. Harris, $\mathrm{MD}^{1,6}$; Ruth Link-Gelles, $\mathrm{PhD}^{1,6}$; Karen Kim, $\mathrm{MD}^{2}$; Edwin Chandrasekar, $\mathrm{MBA}^{2}$; Su Wang, $\mathrm{MD}^{3}$; Nicole Bannister, $\mathrm{MPH}^{3}$; Perry Pong, $\mathrm{MD}^{4}$; Eric Chak, MD ${ }^{5}$; Moon S. Chen, Jr., PhD ${ }^{5}$; Christopher Bowlus, $\mathrm{MD}^{5}$; Noele P. Nelson, MD, $\mathrm{PhD}^{1,6}$

Among an estimated 850,000 to 2.2 million persons with chronic hepatitis B virus (HBV) infection in the United States, $70 \%$ are non-U.S.-born $(1,2)$. All patients require linkage to care, and approximately $20 \%-40 \%$ require antiviral treatment (3).

\section{INSIDE}

547 Outbreaks Associated with Treated Recreational Water — United States, 2000-2014

552 Trends in Antiretroviral Therapy Eligibility and Coverage Among Children Aged <15 Years with HIV Infection - 20 PEPFAR-Supported Sub-Saharan African Countries, 2012-2016

556 Cholera Epidemic — Lusaka, Zambia, October 2017-May 2018

560 Notes from the Field: Outbreak of Vibrio cholerae Associated with Attending a Funeral - Chegutu District, Zimbabwe, 2018

562 Notes from the Field: Investigation of an Outbreak of Salmonella Paratyphi B Variant $\mathrm{L}(+)$ tartrate + (Java) Associated with Ball Python Exposure United States, 2017

565 QuickStats

Continuing Education examination available at https://www.cdc.gov/mmwr/cme/conted_info.html\#weekly.

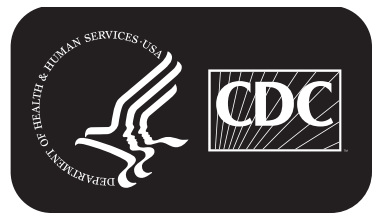

